\title{
Alterations in aggression following GABAergic modulation of septal and raphe activity
}

\author{
M. POTEGAL, A. ANTILLA, and M. GLUSMAN \\ New York State Psychiatric Institute, New York, New York
}

\begin{abstract}
When injected into the septum of muricidal rats, the GABA agonist muscimol substantially reduces muricide latency and increases irritability. Muscimol injections into the dorsal raphe also reduce muricide latency, but such injections into the median raphe increase muricide latency. These raphe injections have no systematic effect on irritability. The GABA antagonist bicuculline has no consistent effect at any site.
\end{abstract}

The work reported here was undertaken for two reasons. First, we had previously observed that intraseptal injection of the GABA agonist muscimol produced a profound facilitation of muricide (Potegal, Yoburn, \& Glusman, 1983). We interpreted this finding as a disinhibition by intraseptal GABAergic elements of the muricideinhibitory output from the septum, which we and others had previously demonstrated by electrical stimulation (e.g., Potegal, Gibbons, \& Glusman, 1980). We thought it of interest to determine whether intraseptal injections of the $\mathrm{GABA}_{\mathrm{a}}$ antagonist bicuculline would have the complementary effect of suppressing muricide.

The second reason for this study was to compare the effects of GABAergic manipulation of the septum to identical manipulations of the dorsal and median raphe nuclei. Like stimulation of the septum, stimulation of the dorsal (but not the median) raphe can inhibit muricide (Potegal, Forte, \& Glusman, 1982; Pucilowski \& Kostowski, 1981). Conversely, lesions of the dorsal raphe, in particular, facilitate muricide (see, e.g., Waldbillig, 1979; Yamamoto \& Ueki, 1977) and defensive aggression (Jacobs \& Cohen, 1976). A more direct link between the septal and raphe effects on muricide is suggested by Gibbons, Potegal, Blau, Ross, and Glusman's (1980) observation that the serotonergic agonist quipazine decreases the threshold current necessary for septal muricide inhibitory stimulation in a statistically significant, dose-related fashion, whereas the serotonergic antagonist metergoline produces an equally significant, dose-related increase. Manipulation of the well-known GABAergic elements in the raphe (e.g., Belin et al., 1983; Nishikawa \& Scatton, 1983 ) is appropriate for our aim of distinguishing between the possible differential involvement of the dorsal and me-

We thank Mrs. Ludmilla Skaredoff for her surgical and histological assistance. This work was supported by Grant 14-039 from the New Yok State Health Research Council and by a grant from the Harry F. Guggenheim Foundation. A. Antilla is currently at Department of Physical Education, Northeastern University, Boston, MA 02115. Address correspondence to M. Potegal, New York State Psychiatric Institute, 722 West 168th St., New York, NY 10032.

Article accepted by previous editor, Patricia Morgan Meyer dian raphe in muricide and irritability, since Sainati and Lorens (1982) have already demonstrated differential behavioral effects of muscimol in these structures.

\section{METHOD}

\section{Subjects and Surgery}

Male Long-Evans hooded rats, 90 to 120 days old, were individually housed and maintained on a $1 \mathrm{~h} /$ day feeding schedule for 7 days. On Day 8 , we screened them for muricide by placing a mouse in each home cage for $5 \mathrm{~min}$; the mouse was removed immediately after being killed. Nineteen of the animals that killed the mouse within the 5-min period were stereotaxically implanted with two 4-mm-long 22-ga guide cannulas (outside diameter, $0.7 \mathrm{~mm}$; Plastic Products $313 \mathrm{G}$ ), one aimed at the septum and the other aimed at either the dorsal or median raphe (implantation coordinates are given in Table 1). The injection cannulas were 28 ga (outside diameter, $0.35 \mathrm{~mm}$; Plastic Products 3131); their lengths are given in Table 1. Surgical-level anesthesia was induced by an intramuscular injection of a mixture of $84 \mathrm{mg} / \mathrm{kg}$ ketamine and $7 \mathrm{mg} / \mathrm{kg}$ xylazine (Rompun, Cutter Labs) and was reversed upon the completion of surgery by $2 \mathrm{mg} / \mathrm{kg}$ yohimbine administered intraperitoneally (Hsu, 1981).

\section{Injection and Testing}

Every subject completed six testing sessions, one session following each of three raphe injections and then each of three septal injections with a minimum 48-h intersession interval. The order of muscimol $(0.5 \mu \mathrm{g})$, saline $(0.5 \mu \mathrm{l})$, and bicuculline $(0.25 \mu \mathrm{g})$ at each of the injection sites was counterbalanced across subjects. The bicuculline was prepared on ice immediately before each injection: (+)bicuculline was dissolved in $0.1 \mathrm{~N} \mathrm{HCl}$ at $0.5 \mathrm{mg} / \mathrm{ml}$, the solution was titrated to $2.5 \leq \mathrm{pH} \leq 3.0$ with a near-saturated $\mathrm{NaOH}$ solution, and the solution was then titrated to $\mathrm{pH} 5.5$ with crystalline $\mathrm{NaHCO}_{3}$.

To ensure a stable baseline of behavior, each session began with a pretest trial; if the subject killed a mouse within $5 \mathrm{~min}$, an injection was given 10 min later. If it did not kill, the trial was aborted and the animal was food-deprived for a day. It was then retested under the same food-deprivation contingency until it killed again, whereupon it was maintained at its new weight. (No rat required more than a total of 3 days of food deprivation; $63 \%$ of the rats required none.) Each drug dose was given in a volume of $0.5 \mu \mathrm{l}$, at an injection rate of $0.5 \mu \mathrm{l} / \mathrm{min}$. To allow diffusion of the agent, the internal cannula was left in place for $30 \mathrm{sec}$ following the injection. A mouse was presented to the rat at 8,23 , and 63 min postinjection. Each mouse presentation trial lasted $5 \mathrm{~min}$ or until 
Table 1

Cannula Implantation Coordinates

\begin{tabular}{lcccc}
\hline \multicolumn{1}{c}{ Structure } & $\begin{array}{c}\text { Cannula } \\
\text { Length (mm) }\end{array}$ & $\begin{array}{c}\text { A-P } \\
\text { Location (mm) }\end{array}$ & $\begin{array}{c}\text { M-L Location } \\
\text { (Midline+mm) }\end{array}$ & $\begin{array}{c}\text { Angle to } \\
\text { Sagittal Plane }\end{array}$ \\
\hline Septum* & 4.5 & $\beta+1.3$ & 0.6 & $0^{\circ}$ \\
Dorsal Raphe $\dagger$ & 6.5 & $0.1 \lambda+0.9 \beta-7.5$ & 2.0 & $18^{\circ}$ \\
Median Raphe $\dagger$ & 8.0 & $0.1 \lambda+0.9 \beta-8.0$ & 2.0 & $14^{\circ}$ \\
\hline
\end{tabular}

Note $-\beta=$ bregma; $\lambda=$ lambda. $\quad$ *A-P location $0.3 \mathrm{~mm}$ anterior to that of Potegal et al., 1983. $†$ A-P location adjusted to skull size as indicated by $\beta-\lambda$ difference. The cannula was inserted at an angle to avoid the aqueduct.

the rat killed (dead mice were removed immediately). To detect any effects of postinjection motoric disturbances, the rat's latency to accept a 0.5 -g chocolate chip offered $3 \mathrm{~min}$ before each mouse presentation (i.e., at 5, 20, and $60 \mathrm{~min}$ postinjection) was also recorded. Data from five post-raphe injection trials and two post-septal injection trials were eliminated because the rat had failed to accept, within $2 \mathrm{~min}$, the chocolate chip offered just preceding those trials.

In all sessions, irritability was measured by response-to-handling tests given $30 \mathrm{~min}$ after the last trial (i.e., $90 \mathrm{~min}$ postinjection). Each test consisted of (1) stroking the (a) back, (b) flank, (c) snout of the rat with tongs; (2) "cornering" the rat with a gloved hand; (3) lifting the rat by the tail; and (4) lifting it by the scruff of the neck. For each of the tests, we scored vocalization ( 0 or 1$)$, escape ( $0-2$, depending on intensity), and biting ( $0-2$, depending on intensity). The cumulative irritability score for each session could range from 0 to 30 .

\section{RESULTS AND DISCUSSION}

For the 12 subjects whose septal cannula tip was within the dorsal and lateral boundaries of the septum or within
$0.5 \mathrm{~mm}$ of the vertical limb of the diagonal band (Figure 1), an analysis of covariance (ANCOVA) of the logtransformed muricide latencies following septal injection revealed a significant effect across drugs $[F(2,19)=10.1$, $p<.002]$. In this ANCOVA and in the subsequent post hoc tests, the preinjection muricide latency was the covariate. Post hoc pairwise tests of covariance showed that the difference between muscimol and bicuculline was highly significant $[F(1,9)=13.5, p<.005]$, as was the difference between muscimol and saline $[F(1,9)=18.3$, $p<.003$ ]; the difference between saline and bicuculline was not significant $[F(1,9)=.31]$. A Friedman nonparametric two-way analysis of variance (ANOVA) indicated a significant effect of drug treatment on irritability $\left[\chi^{2}(2)\right.$ $=10.8, p<.01]$; a post hoc Wilcoxon test $[T(12)=$ $0, p<.01]$ showed this to be due to a median irritability score increase from 2 (saline) to 6.5 (muscimol).

For the 7 subjects whose cannula tips were adjacent to or within $0.8 \mathrm{~mm}$ lateral to the dorsal raphe, there was a trend for muricide latencies following dorsal raphe in-
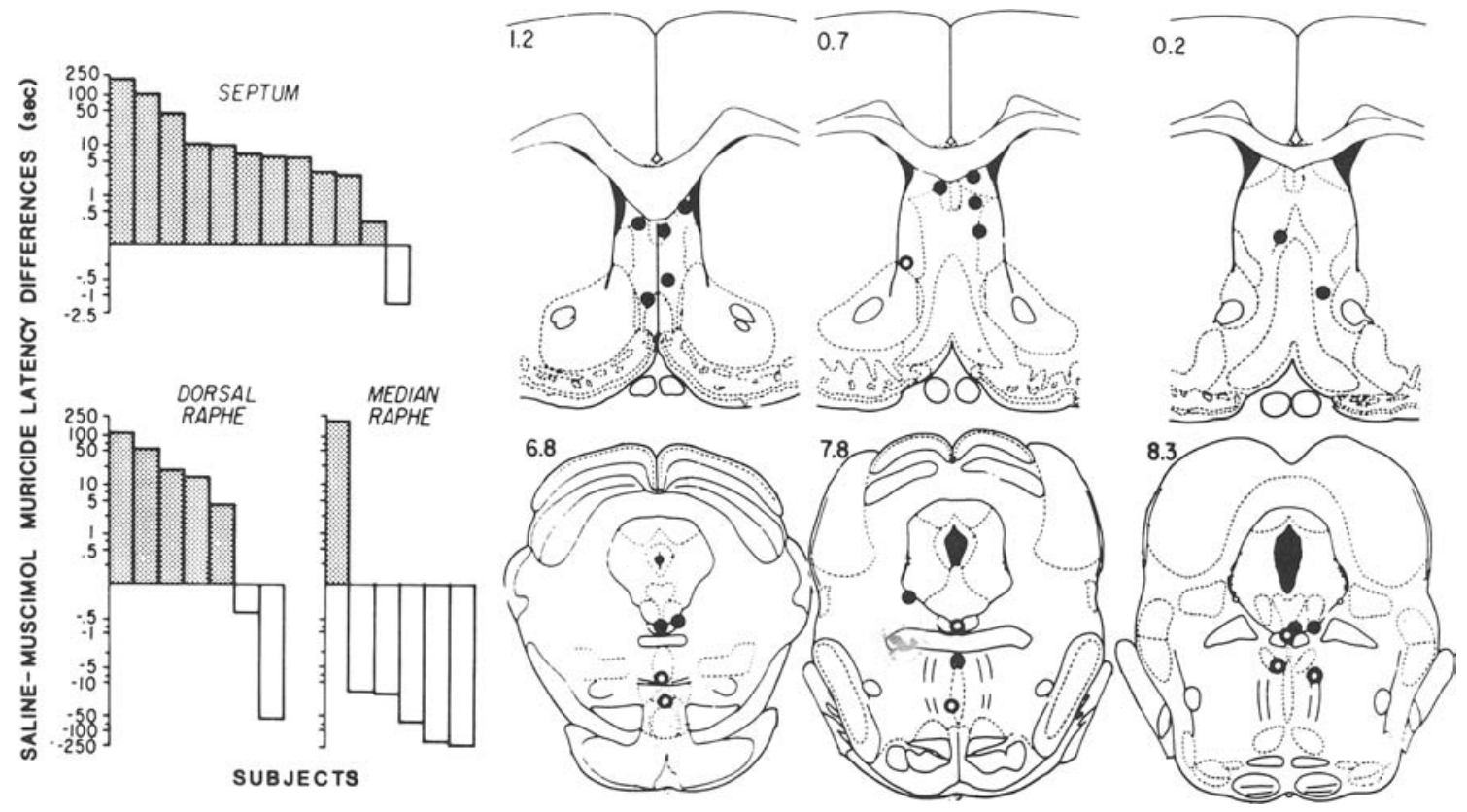

Figure 1. (Left side) Each bar represents the difference between mean muricide latency following intracerebral saline injection less the mean muricide latency following muscimol injection for 1 subject. The ordinate scale is logarithmic. Shaded bars indicate muscimol-induced latency decreases; open bars indicate latency increases. (Right side) Cannula tip positions for each of the subjects whose data is represented to the left are plotted on plates from the Paxinos and Watson (1982) atlas. Numbers in the upper left are distance from bregma. Filled circles correspond to tips at which muscimol injections reduced muricide latency; open circles are tips at which muscimol increased latency. 
jections of muscimol to be reduced below those obtained after saline injections. In contrast, muscimol injections adjacent to or within the median raphe $(n=6)$ increased latencies relative to saline levels (see Figure 1). The significance of the differential changes in latency following dorsal versus median raphe injections was assessed by calculating a saline-muscimol latency change score for each animal. A Mann-Whitney $U$ test between the dorsal and median change scores approached statistical significance $[U(6,7)=9, p=.051]$. The trend for dorsal raphe muscimol injections to reduce muricide latencies is consistent with Waldbillig's (1979) observations on dorsal raphe lesions; the tendency for median raphe muscimol injections to increase muricide latencies is a novel finding deserving further study. There were no significant druginduced changes in irritability, although a trend for irritability to be increased following median raphe muscimol injections is consistent with the trends in Yamamoto and Ueki's (1977) raphe lesion data.

The effects of intraseptal muscimol on muricide and irritability confirm our earlier findings (Potegal et al., 1983) and suggest that the facilitation of muricide observed by Depaulis and Vergnes (1983) following intraventricular injection of THIP may have resulted from the action of this GABA agonist on septal neurons. Our failure to find effects with $0.25-\mu \mathrm{g}$ doses of bicuculline is consistent with other reports that injections of $0.1-0.32 \mu \mathrm{g}$ bicuculline into the raphe have no behavioral or neurochemical effect by themselves (Nishikawa \& Scatton, 1983; Sainati \& Lorens, 1982), although they effectively block the effects of muscimol pretreatment. It is possible that these doses were simply too low; bicuculline doses of 0.6 and $1.8 \mu \mathrm{g}$ have been used to elicit effects from the substantia nigra (Breese, Frye, McCown, \& Mueller, 1984) and periaqueductal grey (Schenberg, de Aquiar, \& Graeff, 1983), respectively. However, the observation that intraraphe bicuculline doses of $0.32 \mu \mathrm{g}$ or less are sufficient for the blockade of muscimol's effects argues against the interpretation that these doses are too low to block endogenous GABA activity. Furthermore, bicuculline doses of only .01 to $0.12 \mu \mathrm{g}$ are adequate to obtain behavioral effects from the medial hypothalamus (Milani \& Graeff, 1987) and various midbrain sites, including the ventral tegmental area (Arnt \& Scheel-Kruger, 1979), inferior colliculus (Breese et al., 1984), and mesencephalic reticular formation (Baumeister \& Frye, 1986). One alternative possibility is that the tonic level of the muricide-disinhibitory GABAergic activity may be so low that it cannot be suppressed further by GABA antagonists. Indeed, the hypothesis that tonic levels of GABA activity are generally low has previously been offered purely on the basis of neurochemical evidence (Blaker, 1985; Wood, Cheney, \& Costa, 1979). This latter conjecture is also consistent with the limited effect we found with the GABA synthesis inhibitor thiosemicarbazide in our previous study (Potegal et al., 1983).
Another possibility is implied by the existence of $\mathrm{GABA}_{\mathrm{a}}$ and $\mathrm{GABA}_{\mathrm{b}}$ receptor subtypes, which have different neuroanatomical distributions (see, e.g., Bowery, Hudson, \& Price, 1987) and different pharmacological and functional characteristics (for a review, see Bowery, Hill, Hudson, \& Price, 1987; Enna, 1987). It may be that the muricide-relevant GABAergic receptors in septum and raphe are the $\mathrm{GABA}_{b}$ subtype, which is, by definition, bicuculline insensitive. Tests of this possibility could be carried out with local injections of the $\mathrm{GABA}_{b}$ agonist baclofen.

\section{REFERENCES}

Arnt, J., \& SChEel-Kruger, J. (1979). GABA in the ventral tegmental area: Effects on locomotion, aggression and food intake after microinjection of GABA agonists and antagonists. Life Sciences, 25 , $1351-1360$

Baumeister, A. A., \& Frye, G. D. (1986). Involvement of the mid brain reticular formation in self-injurious behavior, stereotyped behavior, and analgesia induced by intranigral microinjection of muscimol. Brain Research, 369, 231-242.

Belin, M. F. , Nanopoulos, D., Didier, M., Aguera, M., Steinbusch, H., Verhofstad, A., Maitre, M., \& Puol, J. F. (1983). Immunohistochemical evidence for the presence of aminobutyric acid and serotonin in one nerve cell. A study on the raphe nuclei of the rat using antibodies to glutamate decarboxylase and serotonin. Brain Research, 275, 329-339.

Blaker, W. D. (1985). GABAergic control of the cholinergic projections to the frontal cortex is not tonic. Brain Research, 325, 389-390.

Bowery, N. G., Hill, D. R., Hudson, A. L., \& Price, G. W. (1987). GABA-B receptors. In R. F. Squires (Ed.), GABA and benzodiazepine receptors (Vol. 1, pp. 107-122). Boca Raton, FL: CRC Press.

Bowery, N. G., Hudson, A. L., \& Price, G. W. (1987). GABA and $\mathrm{GABA}_{b}$ receptor site distribution in the rat central nervous system. Neuroscience, 30, 365-383.

Breese, G. R., Frye, G. D., McCown, T. J., \& Mueller, R. A. (1984). Comparison of the CNS effects induced by TRH and bicuculline after microinjection into medial septum, substantia nigra and inferior colliculus: Absence of support for a GABA antagonist action for TRH. Pharmacology, Biochemistry \& Behavior, 21, 145-149.

Depaulus, A., \& Vergnes, M. (1983). Induction of mouse-killing in the rat by intraventricular injection of a GABA-agonist. Physiology \& Behavior, 30, 363-388.

ENNA, S. J. (1987). GABA-A receptors. In R. F. Squires (Ed.), GABA and benzodiazepine receptors (Vol. 1, pp. 91-106). Boca Raton, FL: CRC Press.

Gibbons, J., Potegal, M., Blau, A. D., Ross, S., \& Glusman, M. (1980). Quipazine and metergoline alter thresholds for septal inhibition of muricide. Society for Neuroscience Abstracts, 6, 366.

Hsu, W. H. (1981). Xylazine-induced depression and its antagonism by alpha adrenergic blocking agents. Journal of Pharmacology \& Experimental Therapeutics, 218, 188-192.

JACOBS, B., \& CoHEN, A. (1976). Differential behavioral effects of lesions of the median or dorsal raphe nuclei in rats: Open field and pain elicited aggression. Journal of Comparative \& Physiological Psychology, 90, 102-108.

Milani, H., \& GaEFF, F. G. (1987). GABA-benzodiazepine modulation of aversion in the medial hypothalamus of the rat. Pharmacology, Biochemistry \& Behavior, 28, 21-27.

Nishikawa, T., SCATTON, B. (1983). Evidence for a GABAergic inhibitory influence on serotonergic neurons originating from the dorsal raphe. Brain Research, 279, 325-329.

Paxinos, G., \& WATson, C. (1982). The rat brain in stereotaxic coordinates. New York: Academic Press. 
Potegal, M., Forte, K., \& Glusman, M. (1982). Dorsal raphe lesions and muricide inhibitory septal stimulation. Paper presented at the meeting of the Eastern Psychological Association, Baltimore.

Potegal, M., Gibions, J., \& Glusman, M. (1980). Inhibition of muricide by septal stimulation in rats. Physiology \& Behavior, 24, 863-867.

Potegal, M., Yoburn, B., \& Glusman, M. (1983). Dishibition of muricide and irritability by intraseptal muscimol. Pharmacology, Biochemistry \& Behavior, 19, 663-669.

PucilowskI, O., \& KostowskI, W. (1981). Effects of stimulation of the raphe nuclei on muricide behavior in rats. Pharmacology, Biochemistry \& Behavior, Suppl. 1, 14, 25-28.

SaINat1, S. M., \& LoRENs, S. A. (1982). Intra-raphe muscimol induced hyperactivity depends on ascending serotonin projections. Pharmacology, Biochemistry \& Behavior, 17, 973-986.

Schenberg, L. C., de Aguiar, J. C., \& GraefF, F. G. (1983). GABA modulation of the defense reaction induced by brain electrical stimulation. Physiology \& Behavior, 31, 429-437.

WALDBILLIG, R. (1979). The role of the dorsal and median raphe in the inhibition of muricide. Brain Research, 160, 341-346.

Wood, P. L., Cheney, D. L., \& Costa, E. (1979). An investigation of whether septal $\gamma$-aminobutyrate-containing interneurons are involved in the reduction in the turnover rate of acetylcholine elicited by substance $P$ and $\beta$-endorphin in the hippocampus. Neuroscience, 4, 1479-1484.

Yамамото, T., \& UeKI, S. (1977). Characteristics in aggessive behavior induced by midbrain raphe lesions in rats. Physiology \& Behavior, 19, 105-110.

(Manuscript received April 20, 1985;

revision accepted for publication February 22, 1988.)

\section{Notice}

\section{New Editor of Animal Learning \& Behavior}

Vincent M. LoLordo will assume the editorship of Animal Learning \& Behavior in 1989. After July 1, 1988, manuscripts submitted to Animal Leaming \& Behavior should be sent to him at the Department of Psychology, Dalhousie University, Halifax, Nova Scotia B3H 4J1, Canada. 